\title{
Simulation of Seawater Intrusion in Coastal Aquifers: Forty Five-Years Exploitation in an Eastern Coast Aquifer in NE Tunisia
}

\author{
N. Gaaloul ${ }^{1}$, F. Pliakas ${ }^{2}$, A. Kallioras ${ }^{3, *}$, C. Schuth ${ }^{4}$ and P. Marinos ${ }^{5}$ \\ ${ }^{1}$ National Research Institute for Rural Engineering Water and Forestry (INRGREF-Tunis), Tunisia \\ ${ }^{2}$ Democritus University of Thrace, Department of Civil Engineering, Geotechnical Section, 67100 Xanthi, Greece \\ ${ }^{3}$ National Technical University of Athens, School of Mining \& Metallurgical Engineering, 15780 Zografou, Athens, Greece \\ ${ }^{4}$ Technical University of Darmstadt, Institute of Applied Geosciences, Hydrogeology Group, 64287, Darmstadt, Germany \\ ${ }^{5}$ National Technical University of Athens, School of Civil Engineering, Geotechnical Section, 15780 Zografou, Athens, Greece
}

\begin{abstract}
Management of groundwater resources involves the allocation of groundwater supplies and water quality to competing water demands and uses. The resource allocation problem is characterized by conflicting objectives and complex hydrologic and environmental constraints, especially in coastal aquifers. The development of mathematical simulation models provides groundwater planners with quantitative techniques for analyzing alternatives groundwater resources management. The gathered knowledge was then used to build and to calibrate a 3D transient model of 45 years time period (1963-2008). The numerical model was used further to discuss some issues on the management of the regional groundwater resources. The calibration of the 3D model has been achieved in a time dependent, iterative and semiautomatic fashion. This paper describes a 3-D seawater intrusion modeling process for a specified study area in Eastern Coast aquifer, in NE Tunisia. The simulation results presented in this paper are based on the density-dependent miscible flow and transport modeling approach for simulation of seawater intrusion in coastal aquifers. Response evaluations consider the effects of vertical recharge on seawater intrusion, effects of boundary conditions, and effects of spatially varying pumping from the aquifer.
\end{abstract}

Keywords: Saltwater intrusion, GIS, coastal aquifers, numerical modeling, Tunisia.

\section{INTRODUCTION}

A common problem of aquifers in the Mediterranean region is the degradation of the groundwater quality due to multiple stresses: excessive pumping in relation to average natural recharge, return flow from irrigation water with intense use of agrochemicals. In addition, drought episodes contribute to the degradation of groundwater quality. Increasing access to groundwater plays a key role in alleviating poverty, stabilizing populations and reducing the need for farmers to migrate when drought threatens agricultural livelihoods. Many aquifer systems contain vast quantities of saline water with limited possibilities for exploitation in urban or agricultural supply systems, imposing added stress to those aquifers with water of higher quality.

The research cooperation between the National Research Institute for Rural Engineering, Water and Forestry (INRGREF), Tunisia and the Departments of Civil Engineering of National Technical University of Athens and Democritus University of Thrace have presented the common

*Address correspondence to this author at the National Technical University of Athens, School of Mining \& Metallurgical Engineering, 15780 Zografou, Athens, Greece; Tel: +302107722098; Fax: +302107722117;

E-mail: kallioras@metal.ntua.gr experiences between some typical seawater intrusion study areas in Greece and Tunisia. More specifically, this research describes the main characteristics of two typical Mediterranean coasts, in Greece (Eastern Macedonia and Thrace) and Tunisia (Cap Bon - Eastern Coast), in terms of today's state of seawater intrusion conditions. In Tunisia, agriculture use accounts for approximately $80 \%$ of the total water demands and a large amount of it is poorly used. It is considered to be the sector where the largest volume of water can be saved through better practices. This is one of the main similarities between the two countries, as Greece uses approximately $85 \%$ of the country's water resources for irrigation purposes [1].

The phenomenon of seawater intrusion in Eastern Macedonia and Thrace, in NE Greece, started after the decade of 1950 , as a result of both irrational overexploitation and a negative consequence of the construction of drainage coastal canals. The main negative hydrogeologic result was the serious decline of the piezometric surface of coastal aquifers and the consequent encroachment of seawater into the mainland. The most typical cases of salinisation coastal aquifers in this region are located at coastal plains, and deltas of the rivers of the region. Most of these areas are of significant ecological importance, subjected to international environmental protection treaties. There are several studies dealing with the various cases of seawater intrusion due to extensive over pumping of groundwater resources in Thrace [2-5]), some of 


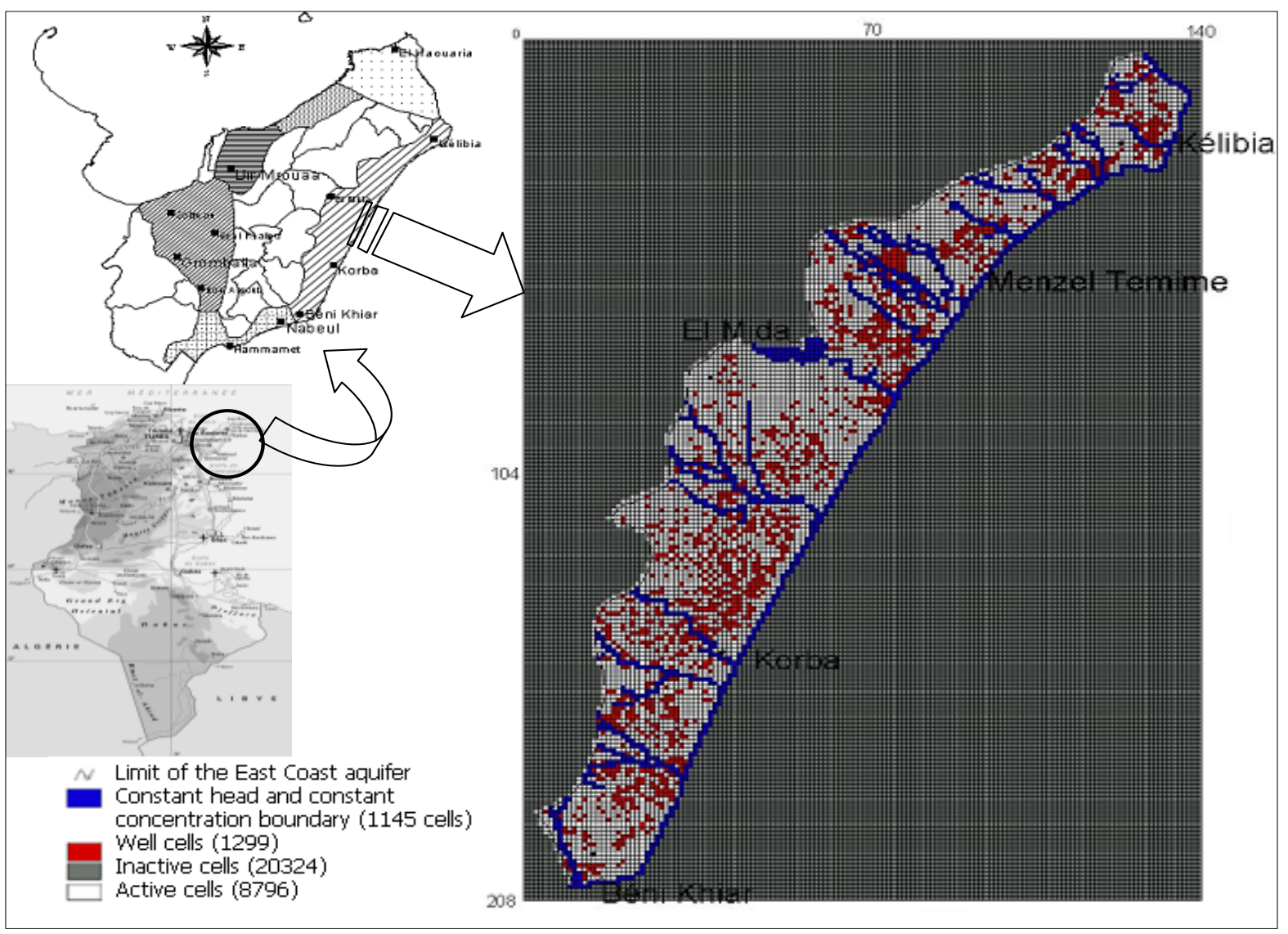

Fig. (1). Location map of the East Coast aquifer in northeastern Tunisia on the Mediterranean Sea, Boundary conditions and finite difference model grid.

which [4] have shown the formation of very deep cones of depression reaching even $35 \mathrm{~m}$ below the mean sea level (in April of 2005).

The Oriental coastal aquifer is situated in the NE CapBon peninsula of Tunisia. Several hydrochemical tests being applied in the area have confirmed aquifer's salinization, showing groundwater salinity range of $1.7 \mathrm{~g} / \mathrm{L}$ to $10 \mathrm{~g} / \mathrm{L}$. Saltwater contamination was first observed in the early 1970s and was recognized as a serious problem in the mid1980s [1].

New technologies are being developed for the prevention of saline intrusion and offer an optimistic scenario for the future. Artificial local recharge is considered as an effective technology in counteracting seawater encroachment and groundwater depletion.

For example, The Korba aquifer is located in the NorthEast of Tunisia (Fig. 1), where a semi-arid Mediterranean climate prevails. It is an important tourist, industrial, and above all agricultural area, with a population approaching 100000 that is concentrated along the coast around the towns of Kelibia in the north and Korba and Ras Marmoura in the south. The dry season is pronounced and this aggravates the situation, given that the highest water demand usually coincides with the drought period (dry weather conditions). The Korba coastal aquifer is pumped by over 7000 wells, extracting about $50 \mathrm{hm} 3 /$ year. Over the last four decades the water table has dramatically decreased and concentrations of salt have increased to peak values of 5 to $10 \mathrm{~g} / \mathrm{L}$ [1].
The hydrochemistry of this coastal aquifer, identifying the main processes that occur in the system, and determine the extent of marine intrusion in the aquifer. The coastal zone is characterized by a low salinity and weak concentrations chloride. The seawater intrusion is accompanied by other processes, which modify the hydrochemistry of the coastal aquifer. Artificial local recharge was applied during the last decade near one of the costal well clusters as a constant rate of $3 \mathrm{hm}^{3} / \mathrm{yr}$, resulting in substantial decrease of the salinity level in the central costal portion of the aquifer. The basin infiltration plant is composed by three infiltration basins of $1500 \mathrm{~m}^{2}$ each (two of them always simultaneously working) feeded by the outflow of a secondary treatment plant. The theoretical water depth of the basin is $200 \mathrm{~mm}$. Average salinity of treated waters for artificial recharge is 3.3g/L. Monitoring of hydraulic parameters has been carried out since the beginning of the facility functioning, but a deep analysis of the recharge impact in the aquifer has not been undertaken.

\section{PRESENT SITUATION OF COASTAL AQUIFER IN NORTHEN AFRICA}

Seawater intrusion (or salt water intrusion) is the encroachment of saline water into fresh ground water regions in coastal aquifer settings. It has been studied extensively for well over a century. An exhaustive review on this topic is provided by [6], and the reader is referred to that text for further information on this topic. 
Saline intrusion is always an important concern in coastal aquifers. Coastal aquifers serve as major sources for freshwater supply in many countries around the world, especially in especially in the Mediterranean. The fact that coastal zones contain some of the densely populated areas in the world makes the need for freshwater even more acute.

The intensive extraction of groundwater from coastal aquifers reduces freshwater outflow to the sea and creates local water table depression, causing seawater to migrate inland and rising toward the wells. This phenomenon, called seawater intrusion, has become one of the major constraints imposed on groundwater utilization. As seawater intrusion progresses, existing pumping wells, especially those close to the coast, become saline and have to be abandoned. Also the area above the intruding seawater wedge is lost as source of natural replenishment to the aquifer. To avoid this trend, which is unsustainable in the long-term, it is necessary to use mathematical models to simulate the phenomenon and to make quantitative estimations of the effects of various management decisions to be taken for problem remedial.

Seawater intrusion is often a major constraint to optimal utilization of fresh groundwater from coastal aquifers. Excessive groundwater abstraction, in response to deteriorating quantity and quality of available surface water resources, has led to large-scale lowering of groundwater tables. Coupled with a continuing sea level rise due to global warming, coastal aquifers are even more under threat. With about $70 \%$ of the world's population living in coastal zones, the challenges are for the optimal exploitation of fresh groundwater and the control of seawater intrusion [6]. The intensity of the problem depends on the amount of the abstraction, in relation to the natural groundwater recharge, but also on the well field location and design, and on the geometry and hydrogeological parameters of the pumped aquifer.

The situation of the groundwater in the Maghreb countries (Egypt, Libya, Tunisia, Algeria and Morocco,) has been marked by continuous decreases of water levels in coastal aquifers reaching alarming values. This decrease, caused by the synergistic effects of drought, flooding, agriculture and urbanization, has intensified the problem of seawater intrusion.

In the Nile delta, seawater intrusion has been observed 60 $\mathrm{km}$ inland as a result of excessive pumping [7]. An extensive saltwater body has developed from upper Egypt to eastern Libya in the past 50 years. The freshwater saline water interface passes through the Qattara depression crossing the Libyan-Egyptian border and finally turning to the $\mathrm{S}-\mathrm{W}$ reaching the Tazerbo area. The development of the Siwa oasis from the deep Nubian Sandstone Aquifer is close to the freshwater/saline water interface, and could cause the saline water to intrude into the freshwater aquifer [8]. The problem is further compounded since on the Libyan side large amounts of water are abstracted for urban development, causing saltwater intrusion along the Libyan coast. This over abstraction in combination with the sluggish flow of the Nubian Sandstone Aquifer causes the saline water body to encroach even further inland with considerable increases in concentration of dissolved solids [9].

In Libya, the city of Derna is facing severe water shortages due to seawater intrusion. The intrusion has steadily increased from 1960 to 2005, a period during which potable water was available; since 2005 , a loss of $75 \%$ in well production in this aquifer system has been observed [10]. Tripoli (Libya) is also affected by saline intrusion, which extends $10 \mathrm{~km}$ inland from the coast; in the Gefara plain, this has been accelerated due to high rates of urbanization and increased agricultural activities [11].

The Korba coastal aquifer situated in Cap-Bon, Tunisia has been experiencing seawater intrusion since 1970 and currently the salt load in this unconfined aquifer has peak concentrations of 5 to $10 \mathrm{~g} / \mathrm{L}$. A large increase in the number of pumping wells for irrigation purposes since the 1960s has resulted in a lowering to below sea level of the water table in several observation piezometers, and in a consequent deterioration of the water quality. A numerical model that treats density-dependent variably saturated flow and miscible salt transport is used to investigate the occurrence of seawater intrusion in the Korba aquifer of the eastern coast of CapBon in northern Tunisia. [1].

The Algerian coastal aquifers have also not escaped over exploitation with the Mitidja aquifer suffering from seawater intrusion, especially during the dry season. This aquifer system has a steady decline in water level in the order of 20-50 $\mathrm{m}$ per decade, which increases the rate of seawater intrusion on an annual basis [12]. The origin of water salinity on the Annaba coast (NE Algeria) is attributed to several factors such as the geological features of the region, the climate and the salted bevel. The salinity increases steadily when approaching the sea, and indicates the influence of marine water [13].

In Morocco, areas have been identified in which saltwater intrusion occurs (Temara-Rabat), however the aquifer system also contains marine deposits which contribute to the degradation of the groundwater. The rates of water abstraction in these areas have increased in the last 50 years, resulting in the lowering of the water table and eventually allowing seawater to intrude from coastal areas [14].

\section{THE DIMENSIONALITY AND HETEROGENEITY EFFECTS ON ADVECTIVE DISPERSIVE SEA- WATER INTRUSION PROCESSES}

Socioeconomical and environmental impacts caused by seawater intrusion (SWI) have claimed the attention of the scientific community worldwide during the last decades. Different approaches have been developed to assess the problem $[6,15]$. The validity and the interest of using numerical models for simulating the dynamics of SWI and as tool for optimal management of coastal aquifers have been extensively illustrated in numerous case studies. In the Mediterranean region, many studies have used groundwater numerical models to assess SWI problems and to design schemes for the optimal management of groundwater resources [16-19, 11, 20-22, 1].

Even if saltwater is a conservative solute, and SWI represents a stable configuration of density-driven flow and solute transport, modeling such phenomenon remains a challenge due to difficulties such as: handling large-scale models with sufficiently detailed resolution, accounting for heterogeneity of hydraulic parameters, estimating effective hydraulic parameters, solving the inverse problem while accounting for all available information, etc. Most often, simplifying assumptions (e.g., use of a sharp interface model, use of a 
broad zonation, reducing the dimension of the problem, fixing parameter values based on numerical mesh resolution, etc.) facilitate the development of a solution. This alleviates partly the intensive calculation demanded for solving the highly nonlinear equations defining SWI processes.

Several strategies have been proposed to prevent or minimize saltwater intrusion in coastal aquifers [6]. These may be grouped into demand actions (reduction or rearrangement of the pattern of groundwater extraction), recharge actions (artificial recharge from spreading basins or recharge wells), relocation of pumping wells (development of a pumping trough by saltwater extraction adjacent to the coast), and additional engineering solutions (maintenance of a freshwater ridge by freshwater injection along the coast; construction of artificial subsurface barriers and land reclamation).

Numerous investigators have performed experimental and numerical studies to understand the dynamics of saltwater intrusion into coastal aquifers [23]. However, these studies do not directly reference saltwater dynamics in cutoff walls. Part of the saltwater intrusion wedge that is trapped as residual saltwater in the storage area of the cutoff wall has been assumed to remain stagnant, but relevant experimental and numerical studies have been conducted to show that saltwater can migrate out of an enclosing barrier. [24] described results from salt-pool experiments that showed saltwater of different densities migrating from a closed system due to freshwater flow from the top.

The seawater intrusion mechanism in coastal aquifers generally causes the occurrence of a freshwater zone over a seawater zone. Freshwater and saltwater are miscible fluids and therefore, the zone separating them takes the form of a transition zone caused by hydrodynamic dispersion. For certain problems, the simulation can be simplified by assuming that each liquid is confined to a well-defined portion of the flow domain with an abrupt interface separating the two domains. When the transition zone is narrow in thickness and area extent, the seawater intrusion phenomenon is modeled as a two-phase fluid flow separated by a sharp interface.

Some of the recently developed simulation models are based on this sharp interface approach. On the other hand, when the transition zone stretches to a considerable extent, the seawater intrusion phenomenon is modeled using the density-dependent miscible flow and transport approach [25, 26]). Coastal aquifers are particularly difficult to simulate numerically because the density of the water and the concentrations of chemical species dissolved in the water can vary substantially throughout the modeled area. A management problem is formulated with two conflicting objectives involving maximization of groundwater development in coastal zones while limiting the head and seawater intrusion to desired levels of salinity by the use of barrier wells.

Unlike many earlier models, the proposed model is based on a recently developed 3-D density-dependent seawater intrusion model, SEAWAT [27]. Use of SEAWAT as the simulator is expected to result in a better representation of the flow system, as compared to the sharp interface approach.

To simulate the seawater intrusion (SWI), one can either adopt a sharp interface or a density-dependent dispersive model [28]. The freshwater and saltwater are considered immiscible. This simplification allows for treatment of the problem analytically or numerically in a very efficient manner. Reviews of this approach can be found in [6]. Despite the fact that assuming a sharp interface allows the development of solutions that are useful for understanding SWI and for solving real-world problems, this approach does not account for hydrodynamic dispersion. However, it is well known that instead of a sharp interface between freshwater and saltwater there is a transition zone since both fluids are miscible. Therefore several methods have been developed to solve the coupled variable-density flow and advectivedispersive solute transport equations. In the case of unstable variable In the case of unstable variable density flow and transport, have shown that heterogeneity can affect transport over many length scales.

In the case of stable SWI, the study of the effect of a layered one-dimensional (1D) heterogeneity on a 2D vertical section assuming a sharp interface model. Related to the question of heterogeneity, one has also to consider the problem of dimensionality when modeling seawater intrusion in a heterogeneous aquifer. Indeed, it is common practice to model groundwater flow and transport problems in $2 \mathrm{D}$ or $1 \mathrm{D}$ because of limited computing resources even if the real problem is $3 \mathrm{D}$. When the reality is assumed homogeneous, exact results can be obtained with a reduced dimension if the appropriate boundary conditions and model size are taken into account. However, this is not sufficient when heterogeneity has to be considered. The choice of dimensionality can lead to significant differences in the outputs of the models. The simulated plume advances farther in a 2D vertical crosssection than in the reference $3 \mathrm{D}$ plume simulation. The vertical averaging of a 3D system would not give sufficiently correct predictions in the case of a vertically extensive plume. The longitudinal and transversal dispersion of the solute plume is underestimated in the case of a 2D simulation (vertical averaging of 3D hydraulic conductivity field). The removal of the vertical dimension and its hydraulic conductivity variability introduces a 5-10\% underestimation of the solute velocities.

The fundamental modification is the assumption that mixing between freshwater and saltwater results from advection and velocity-dependent dispersion processes rather than advection and pure diffusion. The second modification is the use of an anisotropic hydraulic conductivity tensor instead of an isotropic one. These modifications lead to a more realistic simulation of seawater intrusion phenomena, especially more realistic salinity profiles. In the SWI conceptual model, the flow boundary conditions are the same for both versions of the Henry problem and consist of: no flow boundary conditions at the top and bottom of the confined aquifer; a constant flux along the inland boundary; and a hydrostatic pressure distribution along the seaside boundary. In both versions, a concentration equal to 0 is prescribed along the inland boundary. However, in the dispersive version, the concentration along the seaside boundary is imposed only for the entering fluxes.

\section{NUMERICAL MODELS FOR GROUNDWATER MANAGEMENT AND COASTAL AQUIFERS}

The interaction between aquifers and the sea under natural conditions is accompanied by the discharge of fresh 
groundwater into the sea and simultaneous penetration of seawater into fresh aquifers. With the growing water withdrawal from subsurface water intakes in coastal aquifers, the rate of submarine freshwater discharge decreases, which can be the cause of a significant intensification of salt seawater intrusion into fresh aquifers. Thus, the intensification of groundwater development in the Cap Bon since 1970 (because of the increasing aridity of climate) caused a drop in groundwater head below the sea surface in many coastal aquifers.

The result was an intrusion of seawater into fresh coastal aquifers and considerable economic losses. The penetration of seawater into freshwater aquifers affects their water quality and makes them unusable for drinking water supply. Moreover, the water-bearing rocks become saturated with salts; as a result, the deterioration of water quality in subsurface water intakes can persist over many years, even after the intrusion has been eliminated and the natural process of freshwater discharge has recovered. In addition to water withdrawal, the intrusion of marine (salt) waters into freshwater aquifers can be facilitated by engineering activity in the coastal area, such as coastal land reclamation, development of quarries, etc. The richest experience in studying intrusion in hydrogeological examinations of coastal aquifers has been gained in the United States, Japan, Israel, and the Netherlands. In the countries of the former USSR, the problem of seawater intrusion is of importance for some areas in the Baltic region, Kamchatka, and the coasts of the Black and Caspian seas, where seawater shifts toward coastal water intake structures.

In studying the penetration of salt seawater into freshwater aquifers, particular attention is paid to the location of the fresh-salt-water interface and the prediction of water quality dynamics in water intakes operated in marine coastal zones. The intrusion of seawater into aquifers is a complex hydrodynamic process of joint motion of fresh and salt waters, which have different density and other physical properties. The processes taking place in the transition zone from fresh water to salt seawater include dispersion, as well as liquid mixing due to diffusion and advection. The place, shape, and length of the dispersion zone depend on many factors, including the density ratio of salt and fresh waters, the freshwater discharge or head, dispersion characteristics of the aquifer, etc.

A critical role in the quantitative description of the interaction processes between fresh continental waters and salt seawaters belongs to methods of mathematical modeling. The theoretical principles of the mathematical modeling of hydropysical processes in aquifers are represented in a number of monographs. The general class of groundwater systems considered in intrusion problems consists of a saturated porous medium containing a liquid with varying density, depending on the concentration of dissolved salts. Systems of this type can be met in both coastal and inner continental areas. In relatively homogeneous porous media, the denser salt water commonly remains isolated from the overlying freshwater.

However, a mixing or dispersion zone will commonly form between the two liquids. In this zone, part of salt water mixes with fresh water and moves toward the sea, thus causing the motion of seawater toward the mixing zone. The result is the circulation of salt water in coastal aquifers of large thickness. The thickness of the mixing zone can vary within wide limits. As early as the beginning of the past century, W. Badon-Ghyben and A. Herzberg independently established that salt seawater can penetrate far into freshwater aquifers and the occurrence depth salt- fresh water interface is $~ 40$ times greater than the freshwater level in an unconfined aquifer.

Coastal aquifers are a difficult hydrologic environment to represent with a numerical model because of the large number of contributing hydrologic processes, shallow hydraulic gradients, and variable-density flow conditions. The use of groundwater and coastal aquifers models is prevalent in the field of environmental science. Models have been applied to investigate a wide variety of hydrogeologic conditions. More recently, groundwater models are being applied to predict the transport of contaminants for risk evaluation.

In general, models are conceptual descriptions or approximations that describe physical systems using mathematical equations; they are not exact descriptions of physical systems or processes. By mathematically representing a simplified version of a hydrogeological system, reasonable alternative scenarios can be predicted, tested, and compared. The applicability or usefulness of a model depends on how closely the mathematical equations approximate the physical system being modeled. In order to evaluate the applicability or usefulness of a model, it is necessary to have a thorough understanding of the physical system and the assumptions embedded in the derivation of the mathematical equations.

Groundwater models describe the groundwater flow and transport processes using mathematical equations based on certain simplifying assumptions. These assumptions typically involve the direction of flow, geometry of the aquifer, the heterogeneity or anisotropy of sediments or bedrock within the aquifer, the contaminant transport mechanisms and chemical reactions. Because of the simplifying assumptions embedded in the mathematical equations and the many uncertainties in the values of data required by the model, a model must be viewed as an approximation and not an exact duplication of field conditions. Groundwater models, however, even as approximations are a useful investigation tool that groundwater hydrologists may use for a number of applications.

Numerical modeling has emerged over the past 40 years as one of the primary tools that hydrologists use to understand groundwater flow and saltwater movement in coastal aquifers. Numerical models that account for the effects of fluid density on ground water flow are being used more frequently to address scientific, engineering, and water resource management problems. Also being used more frequently are inverse modeling routines based on nonlinear regression methods documented by [29]. As computing power increases and expertise grows, modeling studies will likely use both inverse methods and density-dependent ground water flow simulations to solve complicated water resource or ground water contamination problems. Numerical models are mathematical representations (or approximations) of groundwater systems in which the important physical processes that occur in the systems are represented by mathematical equations. Application of existing groundwater models include water balance (in terms of water quantity), gaining knowledge about the quantitative aspects of the unsaturated zone, simu- 
rated zone, simulating of water flow and chemical migration in the saturated zone including groundwater relations, assessing the impact of changes of the groundwater regime on the environment, setting up/optimising monitoring networks, and setting up groundwater protection zones. The governing equations are solved by mathematical techniques (such as finite-difference or finite-element methods) that are implemented in computer codes. The primary benefit of numerical modeling is that it provides a means to represent, in a simplified way, the key features of what are often complex systems in a form that allows for analysis of past, present, and future groundwater flow and saltwater movement in coastal aquifers. Such analysis is often impractical, or impossible, to do by field studies alone.

Numerical models have been developed to simulate groundwater flow solely or groundwater flows in combination with solute transport (the movement of chemical species through an aquifer). For a number of reasons, numerical models that simulate groundwater flow and solute transport are more difficult to develop and to solve than those that simulate groundwater flow alone. Coastal aquifers are particularly difficult to simulate numerically because the density of the water and the concentrations of chemical species dissolved in the water can vary substantially throughout the modeled area. To address these difficulties, one of two approaches generally is used to simulate freshwater-saltwater interactions [30]. In the first approach, the freshwater and saltwater zones are assumed to be immiscible (that is, they do not mix) and separated by a sharp interface. In the second approach, the freshwater and saltwater are considered being a single fluid having a spatially variable salt concentration that influences the fluid's density; this approach is referred to as density dependent groundwater flow and solute-transport modeling.

Mathematical models are tools, which are frequently used in studying groundwater systems. In general, mathematical models are used to simulate (or to predict) the groundwater flow and in some cases the solute and/or heat transport. Predictive simulations must be viewed as estimates, dependent upon the quality and uncertainty of the input data. Models may be used as predictive tools; however field monitoring must be incorporated to verify model predictions. The best method of eliminating or reducing modeling errors is to apply good hydrogeological judgments and to question the model simulation results. If the results do not make physical sense, find out why.

Scientists and groundwater resources managers are involved in numerical modeling studies of environmental problems, such as contaminant migration prediction, aquifer remediation, seawater intrusion, etc. From a methodological point of view, numerical modeling of such phenomena faces challenges such as characterizing and accounting for complex geological settings. Other challenges are specific to the applications themselves, such as accounting for complex flow and solute transport processes like density effects or reactive solute transport. Those issues affect the accuracy of the forecasts made by numerical models and consequently may affect decisions about groundwater management policies.

Multi-component reactive transport models and variable density flow models are important tools for improving the understanding of governing processes in groundwater sys- tems. Representatives of multi-component reactive transport models are, for example, PHREEQC-II [31], PHAST [32], Hydro Bio Geo Chem [33] and some MODFLOW/MT3DMSbased models such as RT3D [34] and PHT3D [35]. Numerous other models were developed for transport of a single solute species in aquifers with variable density, for example SUTRA [36], METROPOL [37], FEMWATER [38], HST3D [39], NAMMU [40], FEFLOW [41] and MOCDENS3D [42].

SEAWAT [28, 43], couples MODFLOW [44] and MT3DMS [45] to simulate variable density ground water flow. In previous SEAWAT versions, users could simulate transport of multiple chemical species, but fluid density was calculated as a function of solute concentration for only a single species (e.g., salinity, chloride, or relative seawater fraction). Furthermore, previous versions of SEAWAT did not represent the effects of fluid viscosity variations, which can be important for problems with large temperature or salinity variations. To minimize complexity and runtimes, the SEAWAT code uses a one-step lag between solutions of flow and transport. This means that MT3DMS runs for a time step, and then MODFLOW runs for the same time step using the last concentrations from MT3DMS to calculate the density terms in the flow equation. For the next time step, velocities from the current MODFLOW solution are used by MT3DMS to solve the transport equation. For most simulations, the one-step lag does not introduce significant error, and the error can be reduced or evaluated by decreasing the length of the time step. To simulate heat transport within the context of the SEAWAT framework, one of the MT3DMS species is used to represent temperature. The effect of viscosity variations on the resistance to ground water flow also was added through implementation of the relationship between permeability, viscosity, and hydraulic conductivity. Viscosity is incorporated into the flow equation as a function of both temperature and solute concentration (or just one or the other, as desired).

SEAWAT, a combined version of MODFLOW [46] and MT3DMS [45], was designed to solve the three-dimensional variable-density ground-water flow and solute-transport equations using finite-difference methods [28, 43]. Examples of SEAWAT applications include simulation of submarine groundwater discharge to a marine [43] and intercode comparisons [47].

Numerical simulation is used to analyze some of the interactions and possible mechanisms for saltwater intrusion in the Oriental coastal plain of northeastern Tunisia. For the present study, a finite-difference model (SEAWAT) was selected for model simulations.

\section{MODELING EASTERN COASTAL AQUIFER}

The Eastern Coast aquifer study area is located in Northern Tunisia, in Cap Bon and more specifically at its Eastern Coast (Fig. 1). It is an important touristic, industrial, and, above all, agricultural area, with a population approaching 100.000 concentrated along the coast around the towns of Kelibia in the north and Korba and Ras Maamoura in the south. The coastal plain is bounded by the Mediterranean Sea in the east and by the Djbel Sidi AbedErrahmen mountains (anticline) in the west. 


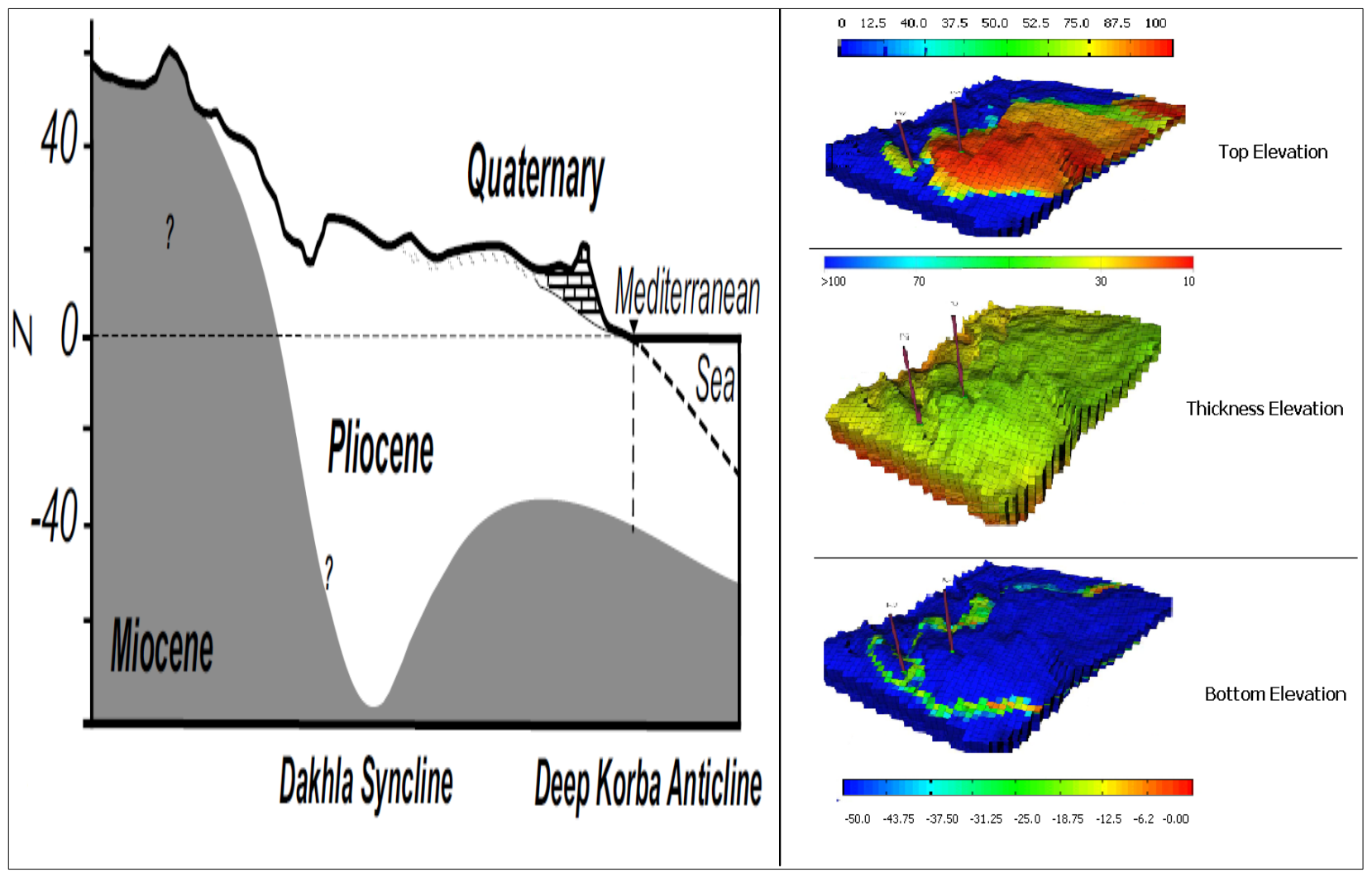

Fig. (2). Geology of the East Coast aquifer in northeastern Tunisia.

The aquifer domain of the study area $\left(475 \mathrm{~km}^{2}\right)$ was discretized using a square cell with dimensions of $250 \times 250 \mathrm{~m}$. The model grid contains 208 rows and 140 columns, resulting in 29120 cells (Fig. 1). One layer was defined to be of increasing thickness from the surface to the base of the aquifer so as to have a sufficiently fine resolution for investigating unsaturated zone processes. The active cells represent the Eastern Coast aquifer, and the inactive cells represent lowpermeability units beneath the Eastern Coast aquifer and the part of the Mediterranean Sea that was not necessary to include. The constant head cells along the right boundary represent the bottom of the Mediterranean Sea, and in two of the simulations the heads in these cells vary with time. These Mediterranean Sea cells also are constant concentration cells with a salinity value of 35 parts per thousand (ppt), the concentration of pure saltwater. General head boundary (GHB) cells are placed along the left boundary to represent connection to the Wadi's (Wadi: dry stream except during periods of rainfall). A coastal head boundary along the coastal zone (eastern boundary) at the top and bottom slices of the aquifer. No flow boundaries are specified in the western boundary. Southern boundary (Wadi K'birr) and left part of the northern boundary (Wadi H'jar) are described by third-kind (Cauchy) boundary condition, Transfer. Internal flow boundaries (Wadi H'jar and Wadi K'bir) are also described by Transfer boundary condition.

The climate is semi-arid, and means annual precipitation is $460 \mathrm{~mm}$ with high annual and interannual variability. The wettest months are November and March, and the driest July and August. Effective infiltration (rainfall minus evaporation and surface runoff) is estimated to be less than $10 \%$ of annual precipitation and as low as $5-7 \%$.
The geological aquifer unit's overly (with an angular discordance) mid-Miocene marls, which form the base of the system. This aquitard may contain lenticular sandstone and clay-sandstone bars of variable thickness and depth but often separated by thick layers. The outcropping formations of the Eastern Coast aquifer are represented by Mio-PlioQuaternary sediments. The unconfined aquifer, formed during the Pliocene and Quaternary ages by deposition of eroded products from the Djbel Sidi AbedErrahmen anticline and the Dakhla syncline, is underlain by a Miocene marl formation and below this stratum by a small and lessexploited confined aquifer (Fig. 2).

The lower part of the Middle Miocene corresponds to detrital deposits known as the Beglia Formation. The Upper Miocene is absent. The trangressional marine Pliocene sediments were unconformably deposited on these folded and eroded formations.

The Pliocene formation is sandstone with alternating marl units, while the Quaternary alluvium is composed of detrital sediment (sand, gravel, and silt) with thin clay lenses. The sandstone formation spans the entire aquifer and has a mean thickness of $85 \mathrm{~m}$, while the detrital formation is less ubiquitous and has a thickness that varies between $20 \mathrm{~m}$ and $25 \mathrm{~m}$. In some parts of the Eastern Coast aquifer the two formations overlap.

The Quaternary deposits are usually composed of two units: the lower unit of marine facies corresponds to sandy limestone with molluscs indicating the maximum flooding surface (MFS) of the Tyrrhenian transgression. The upper unit is mainly composed of a continental facies with the occurrence of oolitic limestone and coprolites or pelloïds. These deposits form, nowadays, coastal consolidated dunes 
built by wind following marine regression. The old consolidated dunes cover the Tyrrhenian deposits. The encrusted limestone extends over significant distances. They are very rich in calcite, silica, sometimes in gypsum and alumina and frequently coloured by iron salts. The aquifers are generally represented by sand formations and sandstone of Quaternary age resting on a series of thick clay of Pliocene age (Fig. 2).

The data sets used in this study were compiled in a Geographic Information System (GIS). Data sets include: rainfall, potential evapotranspiration, soil distribution map, land cover maps, geographical information (ephemeral streams, salt lakes, etc.), geological logs, transmissivity values estimated from pumping tests, piezometric levels, and Total Dissolved Solids measurements. In order to complete the data set and for describing a recent state of the Eastern Coast aquifer. These include well leveling, water table depth measurements and vertical salinity $\log s$ at selected wells. In the parameterization of the model selected hydrogeological attributes were treated as spatially variable, in a block heterogeneity sense according to the presence of either Pliocene sandstone or Quaternary alluvium formations.

The available data for the Eastern Coast aquifer include topographic and soil maps, geological and hydrology, water level and water quality measurements taken from the monitoring wells information relating to agricultural activities and water use, hydrographic and geomorphologic characterizations, and data from meteorological stations. A geographic information system was used to organize these diverse data and to support both pre- and post-processing tasks connected with the saltwater intrusion modeling. Some of the processing, support, and analysis functions performed with the GIS include:

Basic digitizing and manipulation to create data layer and thematic maps: all geographic data was initially available in paper format and at different scales and classifications, and required geo referencing, mosaic king, and assigning of attribute information.

Data conversion and formatting to adapt GIS-processed data for input to the simulation model and to enable GISbased 2D visualization and comparison of model output.

The Eastern Coast aquifer is located in the sand-silt PlioQuaternary formations, characterized by an effective porosity estimated at $12 \%$, an average transmissivity of around $5.10^{-5}$ to $10^{-2} \mathrm{~m}^{2} / \mathrm{s}$ and a storage coefficient of the order of $310^{-5}$ to $210^{-3} \mathrm{~m}^{-1}$. It is a vivid example of overexploitation.

The flow in this aquifer takes several directions but converges generally on the exploitation zone. The flow toward the Mediterranean Sea and toward the sebkha, two natural outlets of the aquifer, is relatively weak due to the strong depression created by the heavy exploitation in the western part of the region. The hydraulic gradients are very variable depending on the lateral facies changes in the aquifer formation and the drawdown linked to the overexploitation. The aquifer is naturally recharged mainly by rainwater and, to a lesser degree, by domestic wastewater from infiltration pits and re-infiltration of some irrigation water. Discharge occurs mainly by pumping for agricultural purposes and into the sea and sebkha. Saltwater intrusion from the sea and/or from the sebkha may disturb the hydrodynamics of the aquifer. All these factors make the water balance of the aquifer extremely complex and its hydrodynamic equilibrium very fragile and, above all, highly variable.

The recharge of the aquifer by infiltration of precipitation is estimated to be less than $10 \%$ of the $440 \mathrm{~mm} / \mathrm{yr}$ average annual rainfall. The integration of this value over the area of interest $\left(400 \mathrm{~km}^{2}\right)$ yields $19 \mathrm{Mm}^{3} / \mathrm{yr}$. Additional recharge from wadis and topographic depressions is also expected. Note however that the most important wadis in the region, Chiba, M'laabi and Lebna were dammed upstream in 1963. Other wadis such as Korba, which drain a watershed of 85 $\mathrm{km}^{2}$, have an average annual runoff of $3.7 \mathrm{Mm}^{3} /$ year estimated the infiltration from wadis in an arid area in the center of Tunisia to $30 \%$ of the annual runoff. According to that study, around $1.1 \mathrm{Mm}^{3} / \mathrm{yr}$ will percolate from wadi Korba to the aquifer, $0.6 \mathrm{Mm}^{3} / \mathrm{yr}$ from wadi Daroufa, $0.8 \mathrm{Mm}^{3} / \mathrm{year}$ from wadi Abids and $0.6 \mathrm{Mm}^{3} / \mathrm{yr}$ from wadi El Malah. Artificial recharge in the region of Diar El Hojjej by direct infiltration of surface water from dams or from the Medjerda Cap-Bon canal started in 1999 but never exceeded 1 $\mathrm{Mm}^{3} /$ year. Other sources of recharge are irrigation return flow (believed to be important) and the lateral recharge by leakage (or through faults) from the underlying Miocene with sandstone are not yet evaluated.

The exploitation of the Korba aquifer began in the 60's mainly for irrigation purposes, and reached $43 \mathrm{Mm}^{3} / \mathrm{yr}$ in the 80 's. In 2008, the total groundwater exploitation was estimated to about $50 \mathrm{Mm}^{3}$ with more than 9000 active wells. It is worth noting that the number of wells is proportional to the number of farms. Regional groundwater is heavily exploited despite the efforts of the government to mobilize most of the regional surface water and to transport water from the north of the country via the Medjerda Cap-Bon canal. Moreover, in the beginning of the 90's, the government encouraged the farmers to adopt drip irrigation systems by contributing to $60 \%$ of the cost of the installation in order to reduce water consumption. The result was that irrigated surfaces increased at the cost of the same water consumption. The sebkhas (salt lakes) forming a $5 \mathrm{~km}^{2}$ strip all along the coastline are suspected to be groundwater discharge areas. Other outputs like submarine groundwater discharge are not yet evaluated.

The above-mentioned incoming magnitudes allow estimating the total recharge in steady state and in the absence of pumping (before 1960), this is of the order of $25 \mathrm{Mm}^{3} /$ year. The total abstraction nowadays represents about twice the amount of recharge. Even without a precise estimation of the other components of the groundwater mass balance, it is selfevident that current overexploitation results in a depletion of the water table and a reduction of the submarine groundwater discharge, which leads to an increase of seawater intrusion.

The groundwater is fed by direct infiltration from precipitation $(440 \mathrm{~mm} / \mathrm{yr})$ and also by the streams, while these recharges are being exceeded by the current rate of exploitation, which is of the order of $19 \times 10^{6} \mathrm{~m}^{3} / \mathrm{yr}$.

In the model, these dominant Pliocene and Quaternary formations are treated as a single unconfined aquifer, albeit assigning to each formation different values for the main hydrogeological parameters; in essence treating the aquifer as a single unit with block heterogeneity. An additional characteristic geomorphologic feature of the Eastern Coast aqui- 

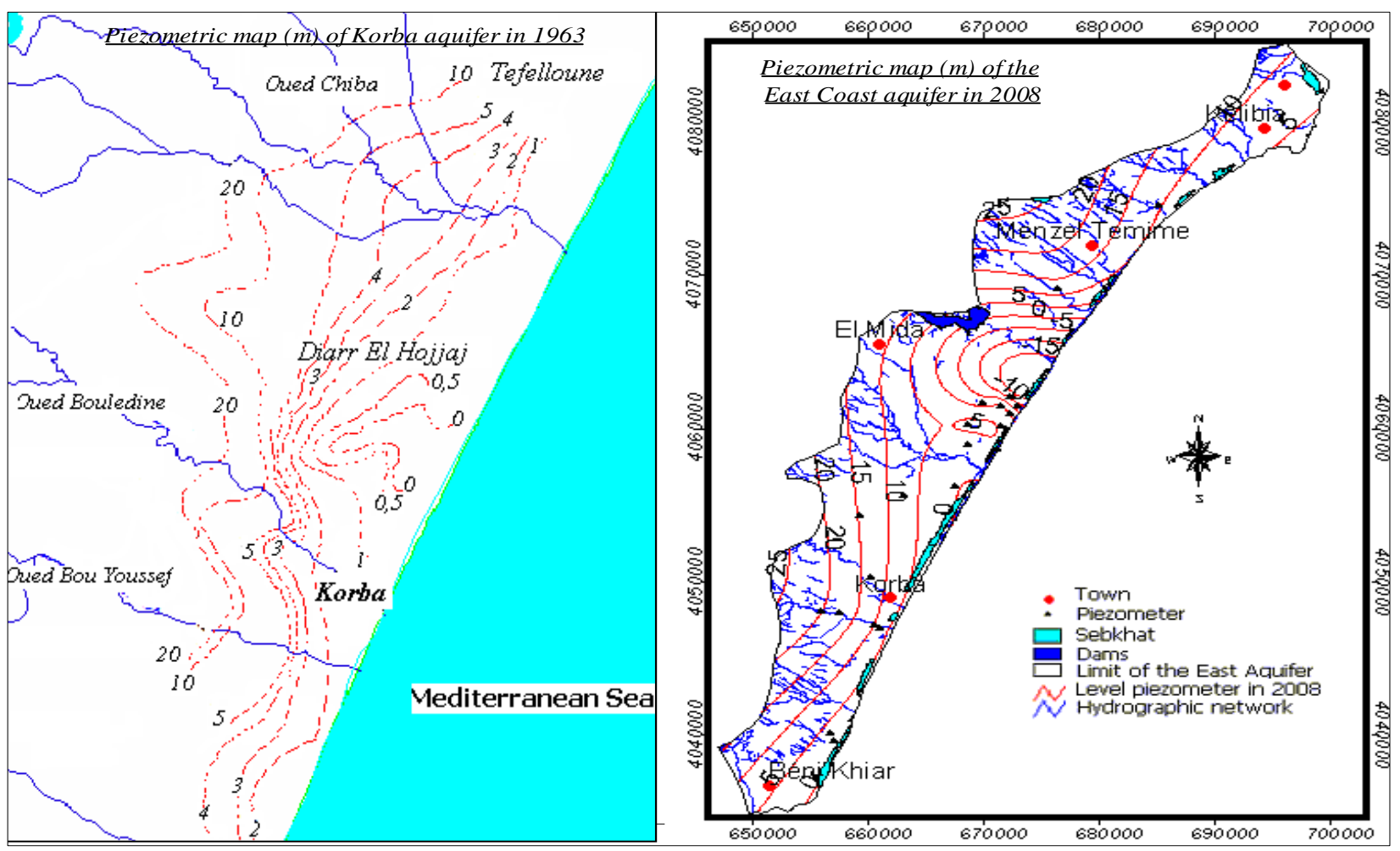

Fig. (3). Observed water table levels (m) from 1963 (left) and 2008 (right) well data showing a general decline in piezometric levels over the 45 years period, and significant drawdown in zones of heavy groundwater pumping.

fer is the dune formation that runs along part of the coastline just east of the second, smaller Menzel Temime anticline. This unit is composed of Quaternary sediments with high hydraulic conductivity, but was not modeled as a distinct block given its small vertical and lateral dimensions relative to the other two formations. The dunes were only indirectly considered in a set of artificial recharge simulations. The boundary conditions and initial concentration for the transient state solute transport are dependent on the flow simulation results. For this model, solute transport concentrations are expressed in terms of total dissolved solids (TDS). A concentration of $36 \mathrm{~g} / \mathrm{l}$ (seawater TDS) is used along the coastal zone where simulated inflow from Mediterranean Sea. The initial concentration of the groundwater was set to $0 \mathrm{mg} / \mathrm{l}$.

Of note in the latest of the two datasets plotted in Figs. (3 and 4) are the localized drops in water table to below sea level and the concentric draw down patterns that have formed. Fig. (3) left displays the evolution of the piezometric level in the Korba aquifer in 1963 as well as the hydrographic network. The piezometric maps of 1963 show that the hydraulic heads in the Korba aquifer were lowered below sea level after 1977 (most likely a few years later, in the 80's when aquifer exploitation reached $43 \mathrm{Mm} 3$ ). A visual comparison of Fig. (3) left and 3 right shows that damming wadi Chiba in 1963 caused a decrease of the groundwater table downstream due to a reduction of recharge by its effluents. In addition to the perturbation of surface water regime, the growth of groundwater abstraction during the 80's (51.5 Mm3 in 1985) especially near the cost, lead to the apparition in 1996 of a concentric depression of $5 \mathrm{~m}$ below sea level in the region of Diar El- Hojjej. This means that the hydraulic gradients were reversed mainly toward the central part of the aquifer leading to an acceleration of seawater intrusion. Indeed, hundreds of wells close to the cost were salinized and then abandoned despite the action of the government forbidding new wells in the area and distributing surface water.

Years after, the depression of Diar El-Hojjej was attenuated and even disappeared, however, pumping migrated northward and led to the apparition of a critical depression of $15 \mathrm{~m}$ below sea level in 2008 (Fig. 3 right). The recent 2008 piezometric map shows piezometric depressions related to overexploitation of the aquifer with negative piezometric levels on the order of $-15 \mathrm{~m}$.

This map (Fig. 3 right) shows a multidirectional flow mainly oriented to the piezometric depressions located at Diar El Hajjej-Garaet Sassi and to the east of Tafelloune. As opposed to the Chiba dam, the Lebna dam (constructed in 1984) had a positive effect on the aquifer recharge.

A monitoring network of 125 wells was set up at he region for acquisition of field data every month, and this data, along with measurements collected from abandoned agricultural wells in 1963 and 2008, show a marked trend towards decreasing water table levels and increasing concentrations of salt in the unconfined aquifer, with peak salinity values of 5 to $15 \mathrm{~g} / \mathrm{L}$ (Fig. 4 left and right). Fig. (3) also shows that the interaction between wadis and the aquifer has been perturbed. Using an average porosity of 0.12 and the depletion of heads from 1963 to 2008 , it is possible to estimate that the total volume of groundwater stored in the central part of the Korba aquifer was reduced by $100 \mathrm{Mm}^{3}$.

Especially regarding the distribution of the salinity values, it can be observed that it reaches a value of $15 \mathrm{~g} / \mathrm{L}$. Impact of this increase in salinity is felt more and more as the 


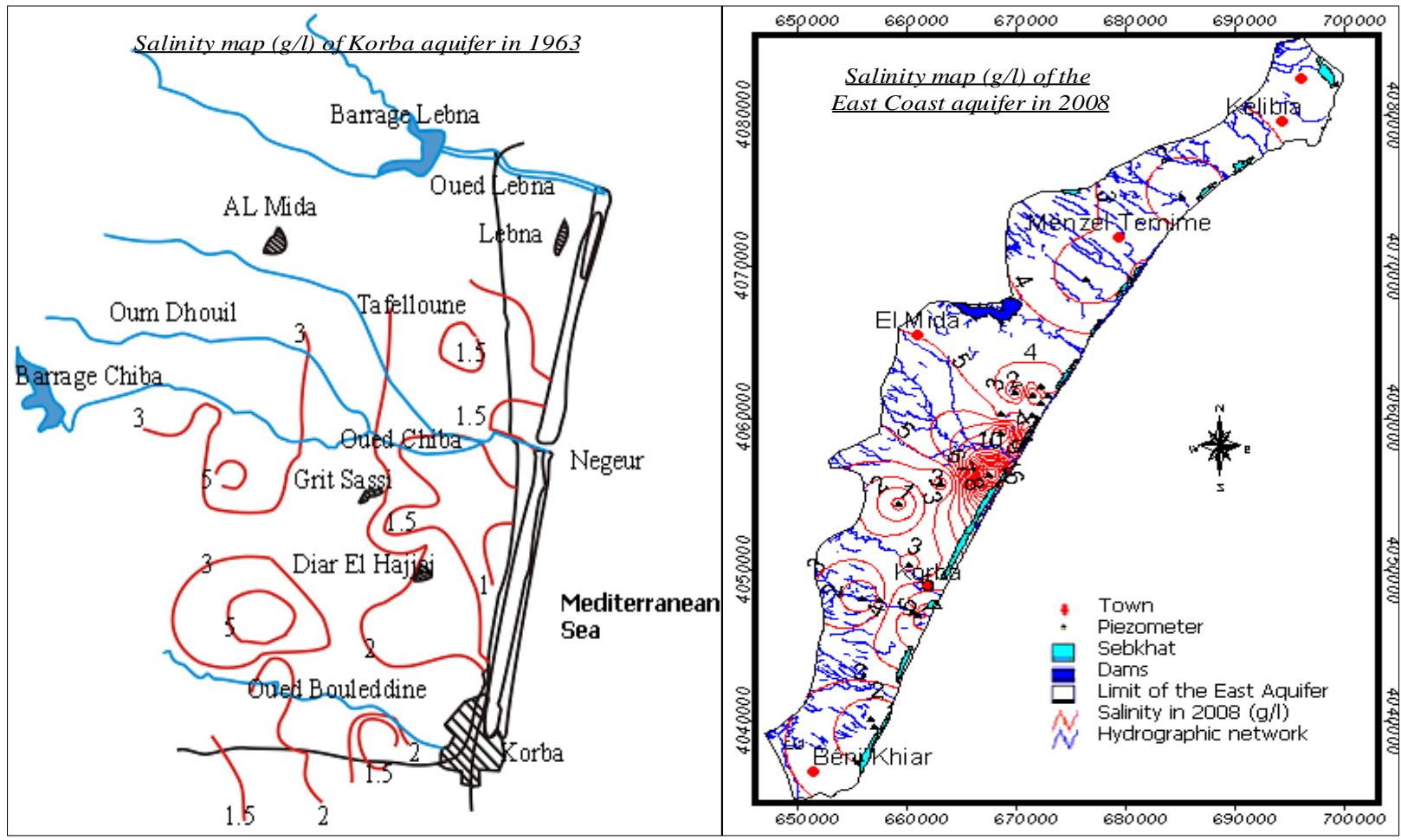

Fig. (4). Observed salinity levels (g/l) from 1963 (left) and 2008 (right) well data showing salinization trend especially near the coast and in zones of heavy groundwater pumping.

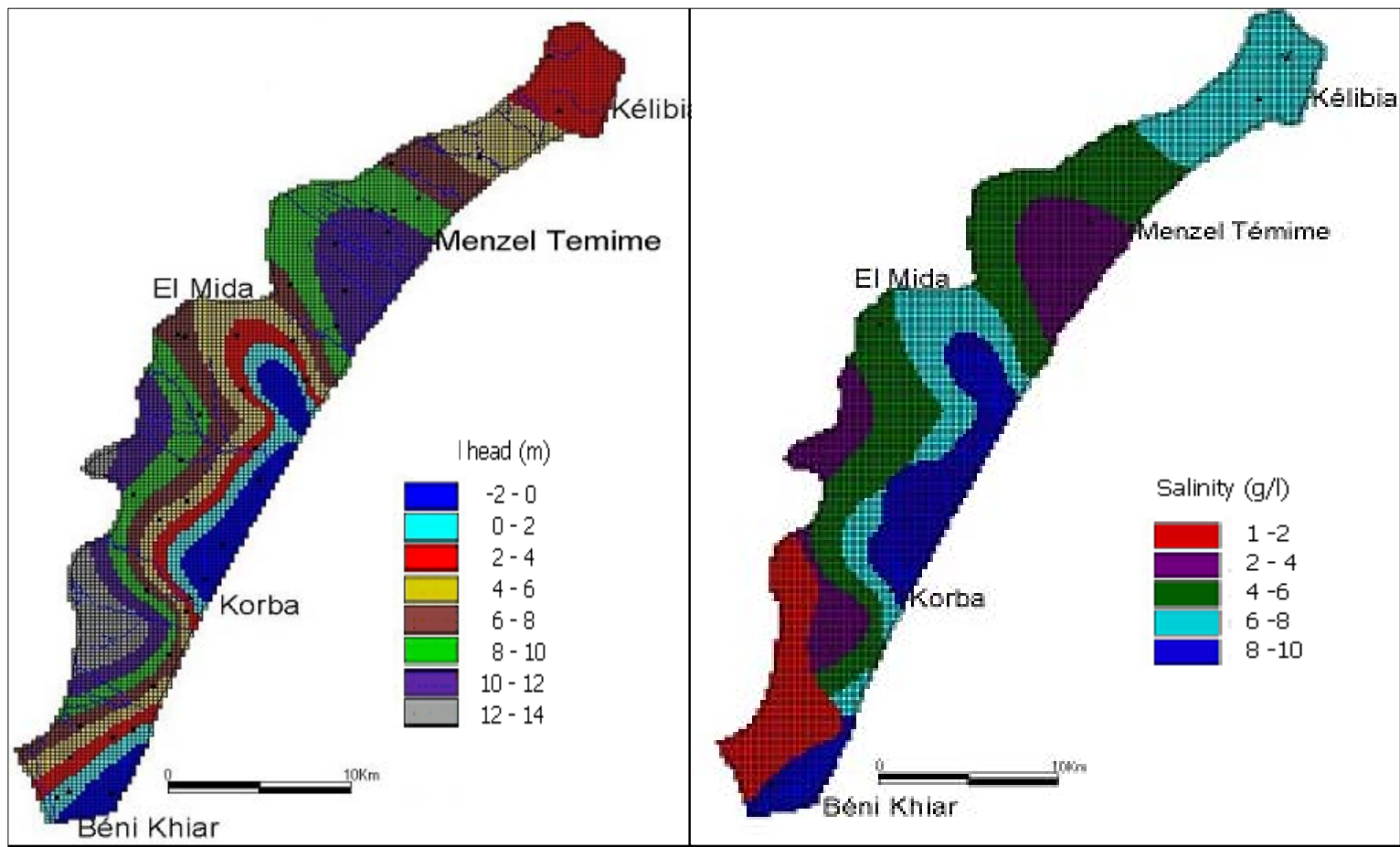

Fig. (5). Piezometric map in 2008 (left), distribution of salinity (in g/L) (right) of the Eastern Coast aquifer simulated by the Model MT3D.

number of abandoned wells keeps on growing. The agricultural production is affected and damage to topsoil has taken place. The deterioration in water quality over the observation period is clearly evident from Fig. (4), and the concentric patterns that are apparent in the latest dataset here as well suggest a strong and direct link between groundwater exploitation and saltwater intrusion.
Increasing population and agricultural activities through the past four decades have led to a steady increase in the amount of water that is pumped from the Eastern Coast aquifer. There are currently over 9000 wells that supply the many small farms and communities in the region, with penetration depths of approximately $25 \mathrm{~m}$ where the aquifer is shallow and approximately $45 \mathrm{~m}$ where it is thicker. To the best avail- 


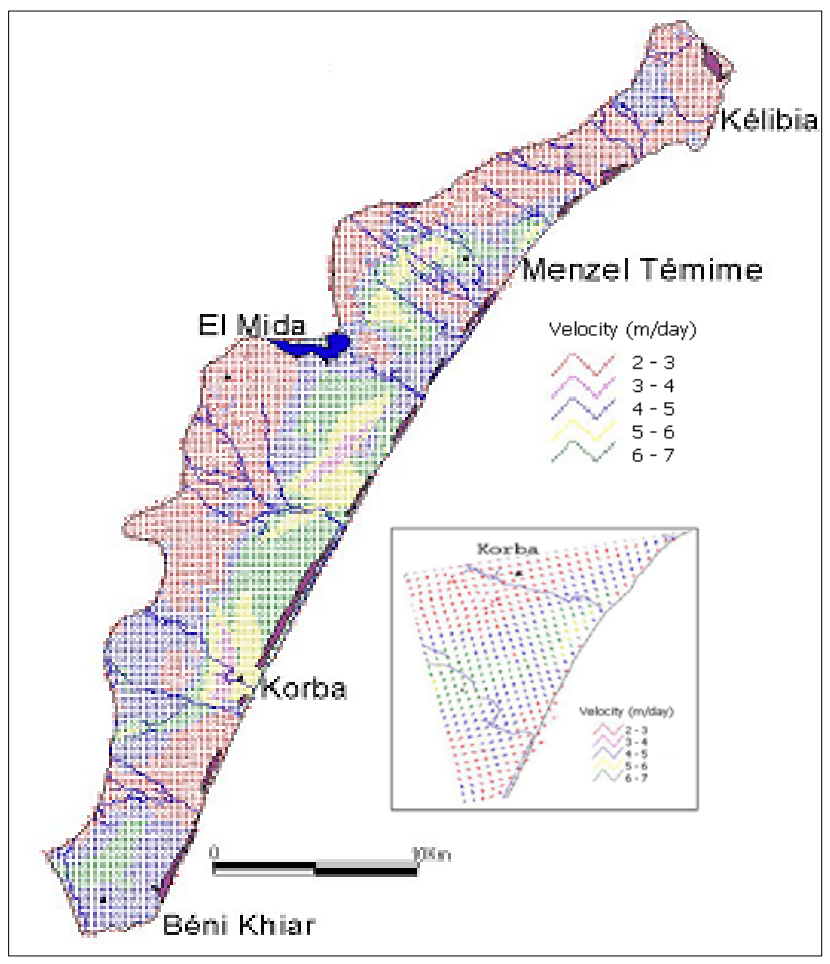

Fig. (6). Velocity (m/day) of the groundwater simulated by the model of the of Eastern Coast aquifer.

able knowledge, the total volume of water pumped from the aquifer in recent years is close to $50 \times 10^{6} \mathrm{~m}^{3} / \mathrm{yr}$. Pumping volumes, together with irrigation rates, are difficult to estimate reliably for the region site, given also the abundance of small-farm private wells in the region. In absence of this detailed data, scenario simulations were again run, and, in particular, the estimated effective infiltration of (less than) $10 \%$ of annual rainfall was relied on. It is interesting to note that, based on these estimates and using $40 \mathrm{~mm}$ as effective annual infiltration, the volume of water recharged to the aquifer from a combination of rainfall and irrigation is approximately $20 \times 10^{6} \mathrm{~m}^{3}$ annually; comparing this value with the $50 \times 10^{6} \mathrm{~m}^{3}$ estimated current annual pumping rate gives an idea of the degree of over-exploitation of the aquifer.

Model simulations of the Oriental coastal aquifer that have been performed include preliminary sensitivity and calibration experiments and two scenarios to investigate the interplay between pumping regimes, effective infiltration, and artificial recharge. Different boundary configurations, grid discretizations, and parameter combinations were tried, and it was observed that the model response was particularly sensitive to effective infiltration rates and saturated conductivities. In calibration trials based on steady state flow simulations, these parameters were varied, within the bounds of available field measurements, until an adequate match was obtained with the observed 1963 piezometric data (Fig. 3 left). The resulting pressure head distribution was then used as the initial flow condition for subsequent transient simulations using the fully coupled model (for the transport component in these transient simulations, a zero concentration initial condition was used throughout the domain). The calibrated, simulated groundwater heads in the Eastern Coast aquifer for the reference 1963 shows good agreement between calculated and measured heads, and the established freshwater-saltwater interface was far away from inland. However, the calibration is more reliable in the North-western sectors and center-East where we have piezometric data.

Worth noticing in the latest of the three datasets plotted in Fig. (5) (left) are the localized drops in water table to below sea level and the concentric draw down patterns that have formed. The deterioration in water quality over the observation period is clearly evident from Fig. (5) (right), which shows salinity values exceeding $10 \mathrm{~g} / \mathrm{L}$. The extent of the saltwater intrusion has been over doubled during the 1963-2008 period.

Fig. (6) shows the velocity (m/day) of the groundwater flow simulated by the model of the of Eastern Coast aquifer.

Fig. (7) shows also the resulting water balance with different components, including the discharge to the Mediterranean Sea.

Due to the important agricultural uses of the Eastern Coast aquifer, several remediation scenarios are being considered for this region, including artificial recharge of the aquifer and construction of small reservoirs to serve as an alternative source of irrigation water. The results show that seawater intrusion would worsen in the aquifer if the current rates of groundwater pumping continue. The alternative, to eliminate pumping in the intruded area, to moderate pumping rates from water supply wells far from the seashore and to increase the aquifer replenishment by encouraging the implementation of suitable solutions like artificial recharge, may limit significantly seawater intrusion and reduce the current rate of decline of the water levels.

\section{CONCLUSIONS - PROPOSALS}

The effect of seawater intrusion on fresh groundwater in coastal areas requires thorough examination, especially now, when its withdrawal for water supply to maritime territories increases. The developed mathematical models of salt seawater intrusion into coastal aquifers allow one to assess the extent of fresh groundwater contamination by marine salts in these regions.

Depending on the concrete hydrogeological conditions and the hydrological regime of the coastal regions, the calculations of the penetration depth of saline seawater into fresh groundwater aquifers can be carried out by two models: in the regime of immiscible liquids and in the regime of advective diffusion (dispersion). The results of simulation of sea salts propagation in a coastal aquifer enables one to more rationally design the layout of groundwater intakes in coastal regions with the aim to ensure the water quality required for domestic water supply.

In the Eastern Coast aquifer in NE Tunisia, a large increase in the number of pumping wells for irrigation purposes since the 1960s has resulted in significant lowering of water table levels in several observation piezometers, and in a consequent deterioration of water quality. This study has used numerical simulation to analyze some of the interactions and possible mechanisms for saltwater intrusion in the study area.

The Eastern Coast aquifer is a dynamic groundwater system, with continuously changing inflow and outflow conditions. The equilibrium condition that once may have existed between fresh and saline water has been disturbed by large 


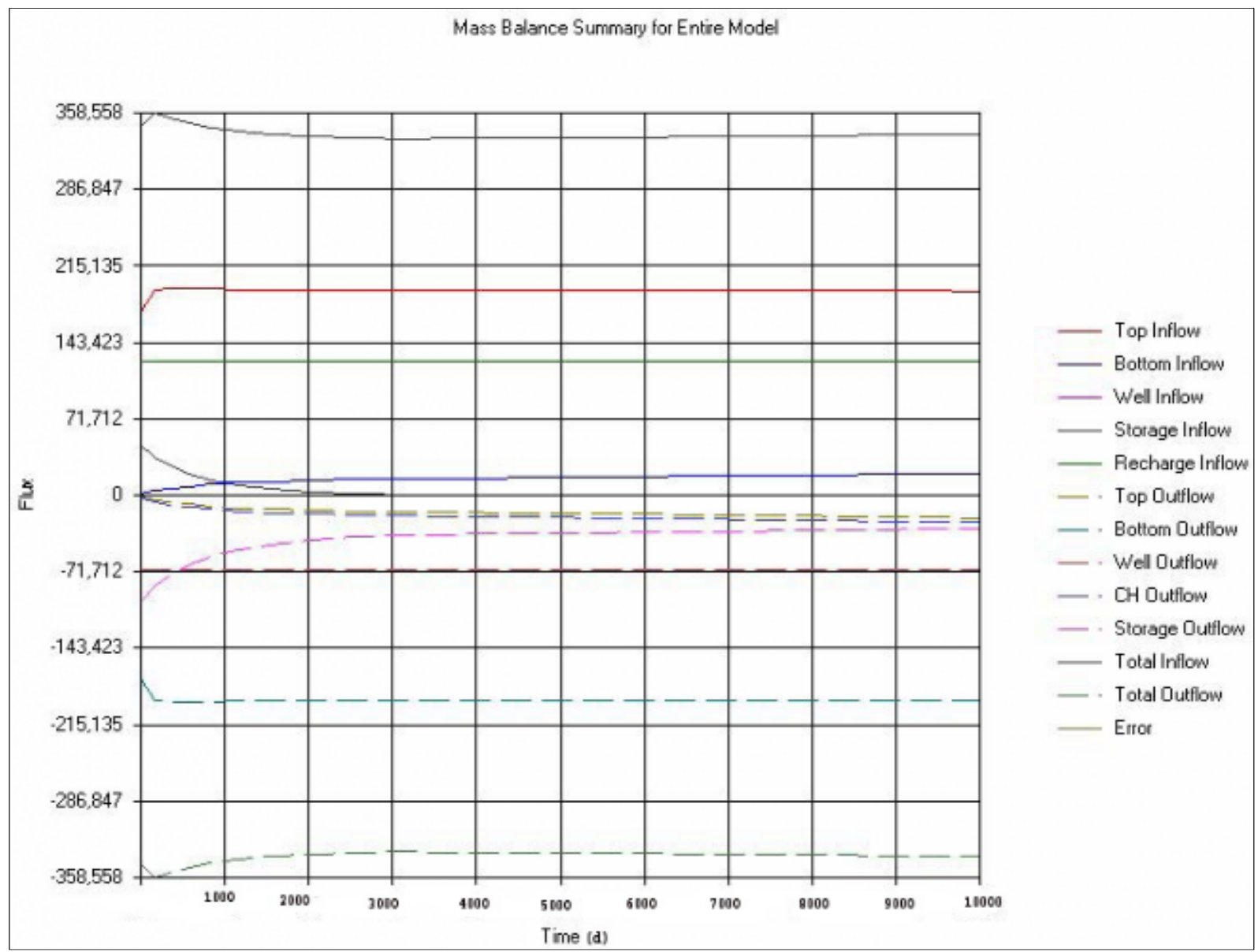

Fig. (7). Mass balance of the Easter Coast aquifer for the transient simulations.

scale pumping. The aquifer has been overexploited for the past 45 years; this has induced seawater flow towards the major pumping centers in the Korba region.

The model gave good results for the study of the evolution of salinity in the aquifer. The preliminary model results suggested that the seawater intrusion began in the 1960s, which is in agreement with the available information about general pumping and well information. Most of the seawater intrusion is happened to the Eastern Coast aquifer.

The results of the modeling procedure led to answering some questions raised by the decision makers and local managers such as:

- To determine the date of the beginning of the seawater intrusion in the aquifer and to follow up its evolution;

- To identify invaded zones by this intrusion, as well as their degree of contamination;

- To quantify the seawater intrusion volume, as well as the other components of the hydraulic mass balance.

Further progress in managing and alleviating the presence of saltwater in the aquifer under investigation will need to rely on more exhaustive field investigations, including continuous monitoring, better aquifer and soil characterization, and assessment or confirmation of the suggested mechanisms for saltwater contamination and interactions between the soil zone, the aquifer, and the sea.
The recovery of groundwater quality is usually a very slow process as seawater intrusion is the result of a longterm negative mass balance in the aquifer. A balance between pumping demand and quality requirements is necessary. This balance is hard to maintain when the final goal is to reverse the qualitative status of the already contaminated aquifer. Some measures are needed to boost the recovery of the aquifer while helping to maintain pumping. These measures can be grouped into actions over the demand (i.e., reduce pumping), actions over the recharge (i.e., artificial recharge and territorial planning), relocation of pumping wells and additional engineering solutions (i.e., seawater intrusion barriers). In this case study, an artificial increase in recharge and specific measures such as a seawater intrusion barrier are proposed to restore groundwater quality in a coastal aquifer suffering from severe seawater intrusion.

Artificial recharge of coastal aquifers, which are especially overexploited, can offer an efficient means of combating seawater intrusion and thus of preventing an inevitable degradation of the water quality which might prove irreversible.

\section{CONFLICT OF INTEREST}

The authors confirms that this article content has no conflicts of interest.

\section{ACKNOWLEDGEMENT}

Declared none. 


\section{REFERENCES}

[1] Gaaloul N, Pliakas F, Kallioras A, Marinos P. Seawater intrusion in Mediterranean porous coastal aquifers: Cases from Tunisia and Greece; In: Migiros G, Stomatis G, Srournaras G. Eds. Proceeding of the 8th International Hydrogeological Congress of Greece; 2008 Oct 8-10; Athens. 2008; pp. 281-90.

[2] Petalas C. Analysis of aquifer systems in the heterogeneous coastal part of prefecture of Rhodope. Doctoral Dissertation. Xanthi, Greece: Department of Civil Engineering, Democritus University of Thrace, 1997; p. 288.

[3] Petalas C, Diamantis I. Origin and distribution of saline groundwaters in the Miocene aquifer system in coastal Rhodope area, Thrace - NE Greece. Hydrogeol J 1999; 7(3): 305-16.

[4] Kallioras A. Management of groundwater resources in aquifers subjected to seawater intrusion regime. The case of the western coastal part of Rhodope Prefecture, Greece. PhD Thesis. Greece: Democritus University of Thrace 2008.

[5] Kallioras A, Pliakas F, Diamantis I. Conceptual model of a coastal aquifer system in northern Greece and assessment of saline vulnerability due to seawater intrusion conditions. J Environ Geol 2006; 51(3); 349-61.

[6] Bear J, Cheng AH-D, Sorek S, Ouazar D, Herrera I. Seawater intrusion in coastal aquifers - concepts, methods and practices. The Netherlands: Kluwer Acad. Pub. 1999; p. 625.

[7] Sherif MM. The Nile Delta aquifer in Egypt, chap 17. In: Bear J, Cheng A, Sorek S, Ouazar D, Herrera A. Eds. Theory and application of transport in porous media, book series. The Netherlands: Kluwer Acad. Pub. 1999; pp. 559-90.

[8] ISARM. Internationally shared (transboundary) aquifer resources management. IHP-VI, IHP Non Serial Publications in Hydrology. November, Paris: UNESCO 2001.

[9] Khouri J. Water resources of the Zarka River basin, Jordan.Water Resources Management and Desertification Problems and Challenges. Geneva: WMO 1996; pp. 84-96.

[10] Elhassadi A. Seawater intrusion in Derna located in the Green Mountain region, Libya: a threatening recurrent phenomenon calling for desalination. Desalination 2008; 220:189-93

[11] Sadeg SA, Karahanoglu N. Numerical assessment of seawater intrusion in the Tripoli region, Libya. Environ Geol 2008; 40: 1151-68.

[12] World Bank. People's Democratic republic of Algeria: a public expenditure review. Assuring High Quality Public Investment. Report No. 36270. Washington, DC: World Bank 2007.

[13] Djabri L, Laouar R, Hani A, Mania J, Mudry J. The origin of water salinity on the Annaba coast (NE Algeria). Proceedings of symposium HSO2a held during IUGG2003 at Sapporo; 2003 July; IAHS Publ. No 280; 2003; pp. 229-35.

[14] Pulido-Bosch A, Tahiri A, Vallejos A. Hydrogeochemical characteristics of processes in the Temara Aquifer in Northwestern Morocco. Water Air Soil Pollut 1999; 114: 323-37.

[15] Cheng AHD, Ouazar D. Coastal aquifer management: monitoring, modeling, and case studies. London: Lewis Publishers 2003.

[16] Galeati G, Gambolati G, Neuman SP. Coupled and partially coupled eulerian-lagrangian model of fresh-water-seawater mixing. Water Resour Res 1992; 28: 149-65

[17] Iribar V, Carrera J, Custodio E, Medina A. Inverse modelling of seawater intrusion in the Llobregat delta deep aquifer. J Hydrol 1997; 198: 226-44

[18] Yakirevich A, Melloul A, Sorek S, Shaath S, Borisov V. Simulation of seawater intrusion into the Khan Yunis area of the Gaza Strip coastal aquifer. Hydrogeol J 1998; 6: 549-59.

[19] Paniconi C, Khlaifi I, Lecca G, Giacomelli A, Tarhouni J. Modeling and analysis of seawater intrusion in the coastal aquifer of eastern Cap-Bon, Tunisia. Transp Porous Media 2001; 43: 3-28.

[20] Aharmouch A, Larabi A, Hilali M. A 3D model for groundwater flow and seawater intrusion interface: Application to the Martil coastal aquifer system. Dev Water Sci 2002; 47: 539-46.

[21] Arfib B, de Marsily G, Ganoulis J. Coastal karst springs in the Mediterranean basin: study of the mechanisms of saline pollution at the Almyros spring (Crete), observations and modelling. Bull Soc Geol France 2002; 173: 245-53.

[22] Milnes E, Renard P. The problem of salt recycling and seawater intrusion in coastal irrigated plains: an example from the Kiti aquifer (Southern Cyprus). J Hydrol 2004; 288: 327-43.

[23] Goswami RR, Clement TP. Laboratory-scale investigation of saltwater intrusion dynamics. Water Resour Res 2007; 43: W04418
[24] Oswald SE, Kinzelbach W. Three-dimensional physical benchmark experiments to test variable-density flow models. J Hydrol 2004; 290: $22-42$.

[25] Essaid HI. A multilayered sharp interface model of coupled freshwater and saltwater in coastal systems: model development and application. Water Resour Res 1990; 27: 1431-54.

[26] Gaaloul N,Cheng AHD. Modeling groundwater flow and seawater intrusion: concepts, methods and practices. University of Mississippi: INRGREF 2003; p. 72.

[27] Guo W, Langevin CD. User's guide to SEAWAT: A computer program for simulation of three-dimensional variable-density ground-water flow. Tallahassee, FL: US Geological Survey Techniques of Water Resources Investigations 2002; p. 77.

[28] Bear J. Seawater intrusion into coastal aquifers. In: Anderson MG, Ed. Encyclopedia of hydrological sciences. Devon, UK: Wiley 2005.

[29] Doherty J. PEST - Model independent parameter estimation. Version 6. Queensland, Australia: Watermark Numerical Computing 2002.

[30] Reilly TE. Analysis of groundwater systems in freshwater-saltwater environments. In: Alley WM, Ed. Regional groundwater quality. New York: Van Nostrand Reinhold 1993; pp. 443-69.

[31] Parkhurst DL, Appelo CAJ. User's Guide to PHREEQC - a Computer Program for Speciation, Reaction-path, 1D-transport, and Inverse Geochemical Calculations. (Version 2) Technical Report 994259. USA: US Geological Survey 1999

[32] Parkhurst DL, Engesgaard P, Kipp KL. Coupling the geochemical model PHREEQC with a 3D multi-component solute transport model. Paper presented at Fifth Annual V.M. Goldschmidt Conference. USA: Geochemical Society, Penn State University, University Park 1995.

[33] Yeh GT, Salvage KM, Gwo JP, Zachara JM, Szecsody JE. HYDROBIOGEOCHEM: a coupled model of HYDROlogic transport and mixed BIOGEOCHEMical kinetic/equilibrium reactions in saturated-unsaturated media. Oak Ridge, USA: Oak Ridge National Laboratory, Center for Computational Sciences 1998.

[34] Clement TP, Sun Y, Hooker BS, Petersen JN. Modeling multispecies reactive transport in ground water. Ground Water Monit Remediat 1998; 18 (2): 79-92.

[35] Prommer H, Barry DA, Zheng C. MODFLOW/MT3DMSbased reactive multicomponent transport modeling. Ground Water 2003; 41(2): 247-57.

[36] Voss CI. A finite-element simulation model for saturated unsaturated, fluid-density-dependent ground-water flow with energy transport or chemically-reactive single-species solute transport. USA: U.S. Geol Surv 1984.

[37] Sauter FJ, Leijnse A, Beusen AHW. METROPOL User's Guide, Report Number 725205003. Bilthoven, Netherlands: National Institute of Public Health and Environmental Protection 1993.

[38] Lin HC, Richards DR, Yeh GT, Cheng JR, Cheng HP, Jones NL. FEMWATER: a three-dimensional finite element computer model for simulating density-dependent flow and transport. Technical report HL-96. USA:US Army Engineer Waterways Experiment Station 1996.

[39] Kipp KL Jr. Guide to the revised heat and solute transport simulator: HST3D Version 2. Water-resources Investigations. Report 974157. Colorado, USA: U.S. Geol Surv 1997.

[40] Herbert AW, Jackson CP, Lever DA. Coupled groundwater flow and solute transport with fluid density strongly dependent on concentration. Water Resour Res 1988; 24(10): 1781-95.

[41] Kolditz O, Ratke R, Diersch H-J, Zielke W. Coupled groundwater flow and transport: 1. Verification of variable density flow and transport models. Adv Water Res 1998; 21(1): 27-46.

[42] Oude Essink GHP. Saltwater intrusion in 3D large-scale aquifers: a Dutch case. Phys Chem Earth 2001; 26 (4): 337-44.

[43] Langevin CD, Shoemaker WB, Guo W. MODFLOW-2000, the US Geological Survey modular ground-water model-documentation of the SEAWAT-2000 version with the variable density flow process (VDF) and the Integrated MT3DMS Transport Process (IMT). Open File Report 03-426. Tallahassee, FL: US Geol Surv 2003; p. 43.

[44] Harbaugh AW, Banta ER, Hill MC, McDonald MG. MODFLOW2000, The US Geological Survey modular ground-water modelUser Guide to modularization concepts and the ground-water flow process. Reston, VA: US Geological Survey 2000; p. 121. 
[45] Zheng C, Wang PP. MT3DMS: A modular three-dimensional multispecies transport model for simulation of advection, dispersion, and chemical reactions of contaminants in groundwater systems; documentation and user's guide, Contract Report SERDP-99-1. Vicksburg, MS: US Army Engineer Research and Development Center 1999; p. 169.
[46] McDonald MG, Harbaugh AW. A modular three dimensional finite-difference ground-water flow model. Book 6 USA: U.S. Geological Survey Techniques of Water Resources Investigations 1988.

[47] Bakker M, Oude Essink GHP, Langevin CD. The rotating movement of three immiscible fluids-a benchmark problem. J Hydrol 2004; $287: 270-8$.

Received: August 10, 2011

Revised: November 30, 2011

Accepted: January 2, 2012

(C) Gaaloul et al.; Licensee Bentham Open.

This is an open access article licensed under the terms of the Creative Commons Attribution Non-Commercial License (http://creativecommons.org/licenses/by-nc/3.0/) which permits unrestricted, non-commercial use, distribution and reproduction in any medium, provided the work is properly cited. 